\title{
Risk assessment of hazardous abrasion and landslide processes in the coastal zone of the Azov Sea
}

\author{
Alexander Khavansky ${ }^{1}$, Vladimir Latun ${ }^{1, *}$, Oleg Khoroshev ${ }^{2}$, Yuliya Merinova ${ }^{1}$, Ludmila \\ Nedoseka ${ }^{1}$ \\ ${ }^{1}$ Southern Federal University, 40, Zorge str., 344000, Rostov-on-Don, Russia \\ ${ }^{2}$ Southern scientific centre of the Russian Academy of Sciences, 41, Chekhov ave., 344000, Rostov- \\ on-Don, Russia
}

\begin{abstract}
The methodology was developed and the socio-economic risk of the manifestation of abrasion and landslide processes in the coastal zone of the Azov Sea was evaluated. The methodology includes assessing the degree of danger of coastal processes and determining possible material losses. The numerical index of socio-economic risk is calculated as the product of point estimates of these parameters. The main factors of dangerous coastal processes formation have been established, according to their similar combination in the coastal zone of the Azov Sea, 42 functional areas and the impact zone of hazardous abrasion and landslide processes predicted for a 20 -year period have been identified. In the forecast zone, 112 socio-economic objects were identified that are subject to the influence of dangerous abrasion and landslide processes. For these socio-economic objects, using the standard set of tools of the public GIS service "Cadastral map of Rosreestr", an enlarged calculation of possible economic damage has been made. The highest values of the socioeconomic risk of the manifestation of abrasion and landslide processes in the coastal zone of the Azov Sea fall on abrasion and abrasion-landslide sections of the coast with a high rate of abrasion, a large number of capital construction projects and a high value of material losses.
\end{abstract}

\section{Introduction}

The length of the coastal zone of the Sea of Azov within Russia is more than $1000 \mathrm{~km}$. On the coast there are urban and rural settlements, port facilities, industrial, social and recreational facilities, roads, electric lines, industrial and agricultural production is carried out, more than 2 million people live here.

The shores of the Azov Sea are subject to dangerous abrasion and landslide processes, which result in the destruction of coasts, residential and industrial buildings, industrial, agricultural and social facilities [1]. Since the southern coast of the Taganrog Bay and the eastern coast of the Azov Sea are characterized by the predominance of large agricultural areas, large agricultural holdings and a fairly low density of settlements, the considered

\footnotetext{
*Corresponding author: vlatun@yandex.ru
} 
hazardous processes primarily violate the integrity of agricultural lands, reduce the number of cultivated areas, and, ultimately as a result, they cause significant damage to the agroindustrial complex of the region.

In this regard, a comprehensive assessment of the current state of the coastal zone, determining the risk of dangerous coastal processes, analyzing the socio-economic and environmental consequences of their manifestation, developing measures to ensure safety and sustainable development of the coastal zone are important.

The works of many scientists are devoted to studies of the ecological state of coastal zone. Significant attention of modern researchers is given to studying theoretical and practical issues of coastal zone development [2]; managing of abrasion processes [3]; identification of problems of coastal zone erosion and pollution $[4,5]$; studying of coastal ecosystems [6,7]; assessing the effectiveness of initiatives for integrated coastal zone management for the formation of coastal sustainability [8]. The tasks of sustainable coastal zone planning [9] are being solved, an assessment of the human impact on the environment is assessed [10,11], the ecological load on the coastal areas is being determined [12], and demographic forecasts for the coastal zone are being created within the framework of the general directions of the socio-economic development of the territory [13]. Existing studies emphasize the need for further development of methods for detecting changes in abrasion processes [14], control over the distribution of sediment [15]; analysis of created databases on coasts and inflammation of gaps existing in them [16].

The aim of the presented study is to develop a methodology and assess the socioeconomic risk of dangerous abrasion and landslide processes in the coastal zone of the Azov Sea.

\section{Materials and methods of research}

According to ISO / IEC standards, risk assessment is a risk analysis and its qualitative or quantitative assessment. In accordance with ISO 31000: 2018, risk assessment is a single process of identification, analysis and risk assessment [17]. To assess the socio-economic risk of the manifestation of abrasion and landslide processes in the coastal zone of the Azov Sea, the danger of coastal processes was identified and possible material losses (damage) were determined. Socio-economic risk - $\mathrm{R}$ is calculated by the formula (1):

$$
\mathrm{R}=\mathrm{D} \times \mathrm{M}
$$

Where $\mathrm{D}$ is the degree of danger of abrasion and landslide processes, $\mathrm{M}$ - material losses.

The methodology for assessing the socio-economic risk of the abrasion and landslide processes manifestation in the coastal zone includes:

- identification of the main factors in the formation of dangerous abrasion and landslide processes;

- allocation of elementary functional sections of the coast with the same combination of factors of formation of dangerous abrasion and landslide processes;

- identification of endangered socio-economic facilities in the coastal zone;

- assessment of the degree of danger of the manifestation of abrasion and landslide processes;

- assessment of possible material losses resulting from the manifestation of abrasion and landslide processes;

- definition of socio-economic risk and its significance for government.

Currently, the Southern Federal University and the Southern Scientific Center of the Russian Academy of Sciences are conducting research to study the geomorphological 
features and patterns of formation of the shores of the Azov Sea, to identify and evaluate dangerous coastal processes $[1,18]$.

Based on these studies, the following main factors can be distinguished for the formation of dangerous abrasion and landslide processes in the coastal zone of the Azov Sea:

- type of coast and nature of coastal processes,

- activity manifestations of abrasion and landslide processes,

- type of economic activity and the nature of development of the coast.

In the coastal zone of the Azov Sea, abrasion, abrasion-landslide and landslide types of dangerous coastal processes are common.

By the nature of the manifestation of the danger, abrasion and landslide processes differ significantly. In general, abrasion processes are relatively uniform and to some extent predictable. Landslide processes are extremely uneven and unpredictable. Abrasionlandslide processes occupy an intermediate position. The activity of the manifestation of dangerous abrasion and landslide processes is determined by the speed of abrasion and the horizontal displacement of landslide bodies. The annual speed of wave destruction of abrasive shores varies between 0.1-6.0 m/year. The horizontal displacement of landslides is $0.1-3.3 \mathrm{~m} /$ year. Long-term studies [18] found that within the coast of the Azov Sea the average coastal retreat rates range from 1.0-1.5 m/year to 4.0-6.0 m/year. According to the activity of manifestations of dangerous abrasion and landslide processes, the coast of the Azov Sea was divided into zones with weak (less than $1 \mathrm{~m} /$ year), medium (1-2 m/year), severe (2-4 m/year) and very severe abrasion (more $4 \mathrm{~m} /$ year). About $30 \%$ of the coasts are characterized by severe abrasion, $33 \%$ of the coasts are covered by very strong abrasion [18].

By the type of economic activity and the nature of the settlement in the coastal zone of the Azov Sea, the following are distinguished: urban settlements and districts, rural settlements, summer cottages, farmland, natural landscapes.

The main technological factors that increase the degree of danger of abrasion and landslide processes in the coastal zone of the Azov Sea include: high density of settlements and intensive economic development of the coast, plowing of land, deforestation, development of irrigated agriculture in the coastal zone.

To take into account the main factors of the coastal zone formation when determining the degree of danger of abrasion and landslide processes, elementary functional sections of the coast were selected, which are homogeneous sections of the coastal zone with a certain (similar) combination of the main factors of its formation (Table 1).

Table 1. The allocation of functional areas in the coastal zone of the Azov Sea.

\begin{tabular}{|c|c|c|c|}
\hline \multicolumn{3}{|c|}{ The main factors in the formation of the coastal zone } & $\begin{array}{l}\text { Functional } \\
\text { area of the }\end{array}$ \\
\hline $\begin{array}{l}\text { Type of economic activity } \\
\text { and nature of the settlement }\end{array}$ & $\begin{array}{c}\text { Types of hazardous } \\
\text { coastal processes }\end{array}$ & $\begin{array}{c}\text { The speed of } \\
\text { abrasion, } \mathrm{m} / \text { year }\end{array}$ & \multirow[b]{2}{*}{$\begin{array}{l}\text { Rozhkovskoye } \\
\text { settlement with } \\
\text { abrasion shore } \\
\text { and medium } \\
\text { abrasion }\end{array}$} \\
\hline $\begin{array}{l}\text { 1. Urban settlements and } \\
\text { counties } \\
\text { 2. Rural settlements } \\
\text { 3. Cottages } \\
\text { 4. Farmland } \\
\text { 5. Natural landscapes }\end{array}$ & $\begin{array}{l}\text { 1. Abrasion } \\
\text { 2. Abrasion- } \\
\text { landslide } \\
\text { 3. Landslide }\end{array}$ & $\begin{array}{l}\text { 1. Weak - less than } 1 \\
\text { 2. Average }-1-4 \\
\text { 3. Severe - more than } \\
4\end{array}$ & \\
\hline
\end{tabular}

The establishment of socio-economic objects subject to the influence of abrasion and landslide processes is carried out in separate functional areas. Such socio-economic facilities include settlements and detached houses, industrial, social and recreational 
facilities, agricultural land, etc., located in the zone of the predicted impact of hazardous abrasion and landslide processes.

Given the great influence of anthropogenic factors that significantly change the conditions for the formation of coastal processes, socio-economic objects located in the coastal zone of urban districts (Taganrog, Yeysk, Primorsko-Akhtarsk) were not considered in this work.

The forecast period is assumed to be 20 years. Based on this, the width of the zone of impact of dangerous abrasion and landslide processes will be: offshore with weak abrasion $20 \mathrm{~m}$, with medium abrasion - $40 \mathrm{~m}$, with severe abrasion - $80 \mathrm{~m}$.

Functional areas and socio-economic objects in the area of the predicted impact of hazardous coastal processes are identified on the basis of the study of cartographic material, satellite imagery, field research, and the collection and analysis of data characterizing the activity and social significance of these objects (Table 2).

For a qualitative assessment of the degree of danger of abrasion and landslide processes in the coastal zone, the system of scoring was used [19]. The degree of danger of abrasion and landslide processes was determined for the functional sections of the coast according to three parameters that characterize: $\mathrm{N}$ - the nature of the manifestations of hazardous processes; $\mathrm{F}$ - features of their distribution; $\mathrm{O}$ - the degree of danger to the population and the economy of hazardous processes. For each of the three parameters, criteria for determining scores have been developed - from 1 to 3 (Table 3).

Table 3. Criteria for determining the degree of danger of the manifestation of abrasion and landslide processes in the coastal zone of the Azov Sea.

\begin{tabular}{|l|c|c|c|}
\hline \multirow{2}{*}{$\begin{array}{c}\text { Parameters of manifestation of } \\
\text { abrasion and landslide processes }\end{array}$} & $\mathbf{3}$ & $\mathbf{2}$ & $\mathbf{3}$ \\
\cline { 2 - 4 } & Score \\
\hline K - type of hazardous coastal processes & Abrasion & Abrasion-landslide & Landslide \\
\hline $\begin{array}{l}\text { P - average coastal abrasion rate, } \\
\text { m/year }\end{array}$ & Less than 1 & $1-4$ & More than 4 \\
\hline $\begin{array}{l}\text { B - the number of socio-economic } \\
\text { objects in the zone of abrasion }\end{array}$ & Less than 3 & $3-10$ & More than 10 \\
\hline
\end{tabular}

The degree of danger of the manifestation of abrasion and landslide processes (Table 4) was calculated as the product of a point estimate of the above parameters (2):

$$
O=K \times P \times B
$$

Assessment of possible material losses was carried out for socio-economic facilities located in the zone of the predicted impact of hazardous abrasion and landslide processes. Using the standard set of tools of the public GIS service "Cadastral map of Rosreestr", the areas of socio-economic objects, their cadastral value were determined and an enlarged calculation of possible economic damage was made (Table 2).

Material losses were converted into points using the following scale:

1 point - losses of less than 1 million rubles, 2 points - $1-5$ million rubles, 3 points - 510 million rubles, 4 points - 10-50 million rubles, 5 points $-50-100$ million rubles, 6 points - more than 100 million rubles. 
Table 2. Functional areas and projected material damage in the coastal zone of the Azov Sea (northern coast of the Taganrog Bay).

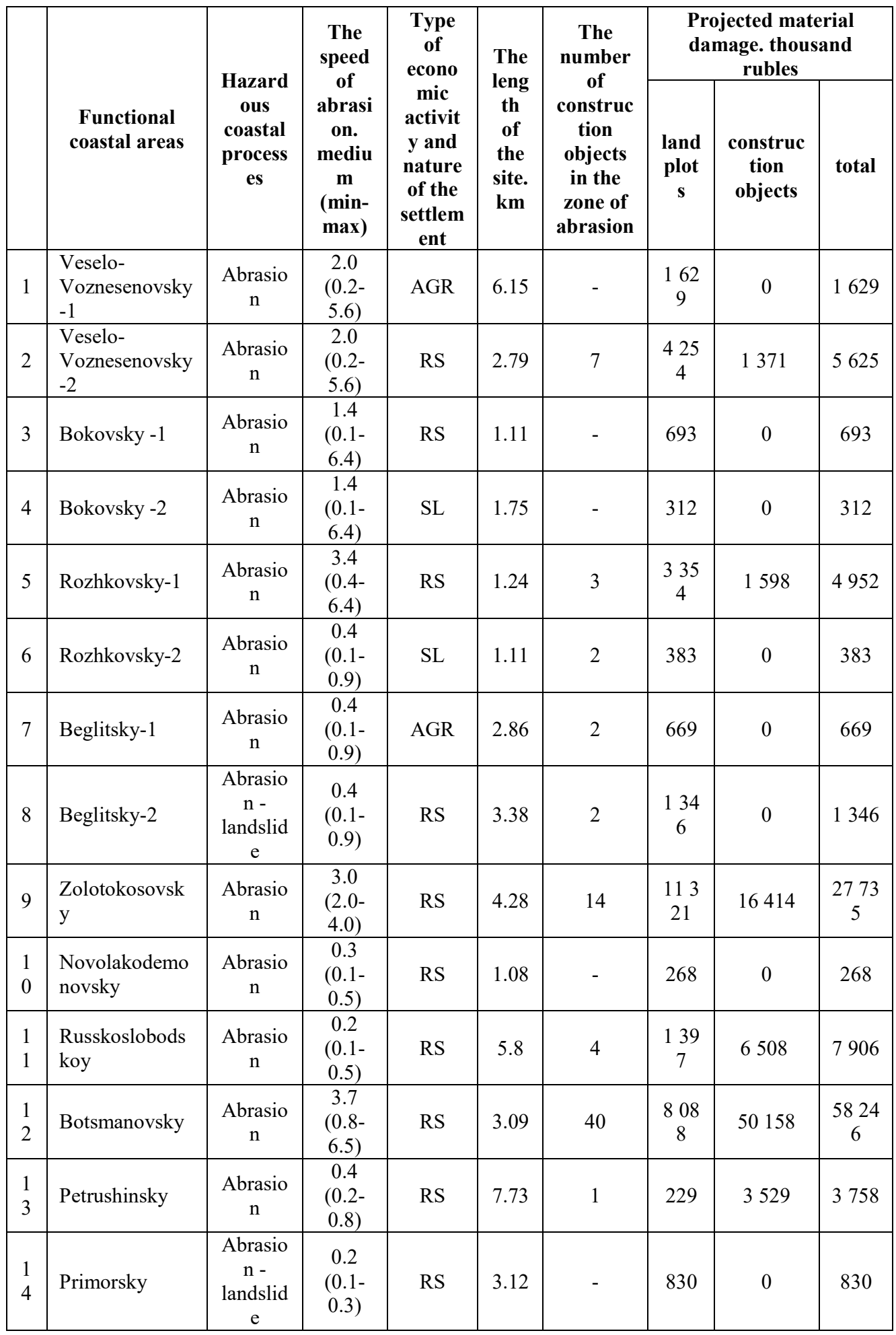




\begin{tabular}{|c|c|c|c|c|c|c|c|c|c|}
\hline $\begin{array}{l}1 \\
5\end{array}$ & Merzhanovsky & $\begin{array}{l}\text { Landsli } \\
\text { de }\end{array}$ & $\begin{array}{c}0.2 \\
(0.1- \\
0.2)\end{array}$ & GNP & 15.8 & - & - & - & - \\
\hline & & & & & & TOTAL: & $\begin{array}{c}347 \\
79\end{array}$ & 79580 & $\begin{array}{c}1143 \\
59 \\
\end{array}$ \\
\hline
\end{tabular}

RS - rural settlements

LS - lands of settlements (residential and recreational zone)

AGR-agricultural land and agricultural land

GNP- garden non-profit partnerships

The calculation of the numerical index of socio-economic risk was carried out in accordance with the above formula, as a product of point estimates of the degree of danger of coastal processes and material losses (Table 4).

Table 4. Risk assessment of hazardous abrasion and landslide processes in the coastal zone of the Azov Sea (northern shore of the Taganrog Bay).

\begin{tabular}{|c|c|c|c|c|c|c|c|}
\hline & \multirow[t]{2}{*}{$\begin{array}{c}\text { Functional area of the } \\
\text { coast }\end{array}$} & \multicolumn{3}{|c|}{$\begin{array}{c}\text { Danger } \\
\text { Parameters }\end{array}$} & \multirow{2}{*}{$\begin{array}{c}\text { Danger } \\
\text { Degree } \\
\mathbf{O}=\mathbf{K} \times \mathbf{P} \times \mathbf{B}\end{array}$} & \multirow{2}{*}{$\begin{array}{c}\text { Material } \\
\text { loss ratio } \\
\text { M }\end{array}$} & \multirow{2}{*}{$\begin{array}{l}\text { Numerical } \\
\text { risk index } \\
\mathbf{R}=\mathbf{O} \times \mathbf{M}\end{array}$} \\
\hline & & $\mathbf{K}$ & $\mathbf{P}$ & B & & & \\
\hline 1 & Veselo-Voznesenovsky -1 & 1 & 2 & 1 & 2 & 2 & 4 \\
\hline 2 & Veselo-Voznesenovsky -2 & 1 & 2 & 2 & 4 & 3 & 12 \\
\hline 3 & Bokovsky -1 & 1 & 2 & 1 & 2 & 1 & 2 \\
\hline 4 & Bokovsky-2 & 1 & 2 & 1 & 2 & 1 & 2 \\
\hline 5 & Rozhkovsky-1 & 1 & 3 & 2 & 6 & 3 & 18 \\
\hline 6 & Rozhkovsky-2 & 1 & 1 & 1 & 1 & 1 & 1 \\
\hline 7 & Beglitsky-1 & 1 & 1 & 1 & 1 & 1 & 1 \\
\hline 8 & Beglitsky-2 & 2 & 1 & 1 & 2 & 2 & 4 \\
\hline 9 & Zolotokosovsky & 1 & 3 & 3 & 9 & 4 & 36 \\
\hline 10 & Novolakodemonovsky & 1 & 1 & 1 & 1 & 1 & 1 \\
\hline 11 & Russkoslobodskoy & 1 & 1 & 2 & 2 & 3 & 6 \\
\hline 12 & Botsmanovsky & 1 & 3 & 3 & 9 & 5 & 45 \\
\hline 13 & Petrushinsky & 2 & 1 & 1 & 2 & 2 & 4 \\
\hline 14 & Primorsky & 2 & 1 & 1 & 2 & 1 & 2 \\
\hline 15 & Merzhanovsky & 3 & 1 & 1 & 3 & 1 & 3 \\
\hline
\end{tabular}

\section{Results and discussion}

In the coastal zone of the Azov Sea, 42 functional areas have been identified, characterized by the same type of combination of the main factors in the formation of dangerous coastal processes. This made it possible to predict the development of dangerous coastal processes taking into account the specific natural and anthropogenic conditions of each section of the coastal zone.

In the projected for a 20-year period impact zone of hazardous abrasion and landslide processes there are 112 socio-economic facilities, including residential buildings, industrial facilities, educational institutions, hotels, etc., of which 75 are located on the northern shore of the Taganrog Bay, 13 are located in the southern coast of the Taganrog Bay and 24 on the eastern coast of the Azov Sea (Table 5).

Table 5. The main indicators of the predicted impact of abrasion and landslide processes in the coastal zone of the Azov Sea.

\begin{tabular}{|c|c|c|c|c|c|}
\hline \multirow[t]{2}{*}{ Coastal areas } & \multirow{2}{*}{$\begin{array}{c}\text { Number of } \\
\text { functional areas }\end{array}$} & \multirow{2}{*}{$\begin{array}{l}\text { Number of socio- } \\
\text { economic objects }\end{array}$} & \multicolumn{3}{|c|}{ Material losses. million rubles } \\
\hline & & & $\begin{array}{l}\text { land } \\
\text { plots }\end{array}$ & $\begin{array}{l}\text { constructi } \\
\text { on objects }\end{array}$ & Total \\
\hline The northern coast of & 15 & 75 & 34.8 & 79.6 & 114.4 \\
\hline
\end{tabular}




\begin{tabular}{|l|c|c|c|c|c|}
\hline the Taganrog Bay & & & & & \\
\hline $\begin{array}{l}\text { The southern coast of } \\
\text { the Taganrog Bay }\end{array}$ & 18 & 13 & 261.3 & 11.3 & 272.5 \\
\hline $\begin{array}{l}\text { The eastern coast of } \\
\text { the Azov Sea }\end{array}$ & 9 & 24 & 220.2 & 184.0 & 404.2 \\
\hline Total & 42 & 112 & 516.3 & 274.9 & 791.1 \\
\hline
\end{tabular}

The increased hazard values for the manifestation of abrasion and landslide processes in the coastal zone of the Sea of Azov are distinguished by abrasion and abrasion-landslide sections of the coast with a high rate of abrasion and a large number of capital construction projects.

Possible material losses due to the manifestation of abrasion and landslide processes in the coastal zone of the Azov Sea during the forecasted 20-year period will amount to: 114.4 million rubles for the northern coast of the Taganrog Bay, 272.5 million rubles for the southern coast of the Taganrog Bay, the eastern coast of the Azov Sea is 404.2 million rubles, a total of 791.1 million rubles. (Table 5).

The structure of economic damage is dominated by losses associated with the loss of farmland due to their large area and relatively low development of the southern coast of the Taganrog Bay and the eastern coast of the Sea of Azov. The numerical index of socioeconomic risk of the manifestation of abrasion and landslide processes in the coastal zone of the Azov Sea varies from 1 to 48. The most dangerous areas of the manifestation of abrasion and landslide processes in the coastal zone of the Azov Sea are: Peresyp numerical risk index 48, Botzmanovsky - 45, Zolotokosovsky - 36, Rozhkovsky-1 - 18.

\section{Conclusions}

1. The developed methodology for assessing the socio-economic risk of the manifestation of abrasion and landslide processes includes assessing the degree of danger of coastal processes and determining possible material losses. The numerical index of socio-economic risk is calculated as the product of point estimates of these parameters.

2. The highest values of the socio-economic risk of the manifestation of abrasion and landslide processes in the coastal zone of the Azov Sea fall on abrasion and abrasionlandslide sections of the coast with a high rate of abrasion, a large number of capital construction projects and a high value of material losses.

3. The projected material losses from the impact of hazardous abrasion and landslide processes in the coastal zone of the Azov Sea over a 20-year period will amount to 791.1 million rubles, of which 274.9 million rubles are accounted for by capital buildings and 516.3 million rubles on land, mainly agricultural land.

\section{Acknowleddgements}

This work was carried out in the framework of the scientific project of the Russian Foundation for Basic Research (RFBR) No. 18-05-80082 on the topic "Patterns of formation of dangerous coastal processes in the Sea of Azov and the socio-economic consequences of their manifestations".

\section{References}

1. G.G. Matishov, S.V. Berdnikov, L.A. Bespalova, O.V. Ivlieva et al., Modern dangerous exogenous processes in the coastal zone of the Sea of Azov: monograph (Publishing House of the Southern Federal University, Rostov-on-Don, 2015) 
2. M.M. El-Hattab Masria, A. Negm, M. Iskander, O. Saavedra, Procedia Engineering 70, 1102-1111 (2014)

3. R. Rostika, N. Primadona Purba, M. Lutfi, J. Kelvin, I. Silalahi, Procedia Environmental Sciences 33, 512-519 (2016)

4. J.H. Brand, K.L. Spencer, Marine Pollution Bulletin 146, 282-291 (2019)

5. U. Hasdinar, R. Sabaruddin, A. Yasir Baeda, K. Syerly, Procedia Engineering 116, 125-133 (2015)

6. I. Kvalvik, A.-M. Solas, P. Berg Sordahl, Ecosystem Services 42, 101071 (2020)

7. Yan $\mathrm{Xu}$, Yanpeng Cai, Jianfeng Peng, Jiuhui Qu, Zhifeng Yang, Global Ecology and Conservation 20, e00764 (2019)

8. Y. Beeharry, T. Makoondlall-Chadee, C. Bokhoree, APCBEE Procedia 9, 30-35 (2014)

9. Yi Chang, Ka-wai Chu, L. Zsu-Hsin Chuang, Landscape and Urban Planning 174, 2432 (2018)

10. S. Aswani, Biological Conservation 236, 223-235 (2019)

11. J.H. Andersen, Z. Al-Hamdani, E. Thérèse Harvey, E. Kallenbach, A. Stock, Science of The Total Environment 70420, 135316 (2020)

12. M. Mali, N. Ungaro, A. Cardellicchio, M. Michela Dell'Anna, L. Damiani, Ecological Indicators 101, 838-850 (2019)

13. J.-L. Merkens, L. Reimann, J. Hinkel, A.T. Vafeidis, Global and Planetary Change 145, 57-66 (2016)

14. The Egyptian Journal of Remote Sensing and Space Science 19(1), 23-36 (2016)

15. S.Y. Johnson, J.W. Beeson, J.T. Watt, R.W. Sliter, A.G. Papesh, USA Marine Geology 420, 106085 (2020)

16. D. Astiaso Garcia, M. Amori, F. Giovanardi, G. Piras, L. de Santoli, Science of The Total Environment 66810, 531-546 (2019)

17. ISO 31000:2018 Management du risque — Lignes directrices

18. G.G. Matishov, L.A. Bespalova, O.V. Ivlieva, A.E. Tsygankova, L.V. Kropyanko, Reports of the Academy of Sciences 471(4), 1-4 (2016)

19. A. Khovansky, I. Bogachev, E. Bayan, Ecology and Industry of Russia 20(10), 58-63 (2016) doi: 10.18412 / 1816-0395-2016-10- 58-63. 